\title{
The City in these Two Faces of Power: Study of Social Reality Actors in Ternate North Maluku, Indonesia
}

\author{
Herman Usman
}

Department of Sociology Muhammadiyah University of North Maluku, KH. Ahmad Dahlan Street No. 100 Ternate City, Indonesia

\begin{abstract}
This study examined the existence of Ternate City that known as the region on the one hand has the power custom through the structure of the Sultanate of Ternate, and on the other hand, into a modern city with the structure of government bureaucracy. The relation of two powers, sometimes spawned opposition and conflict (dualism), sometimes also present the mutual relations (duality), mutually beneficial. The analysis of the city with the two powers, by using qualitative methods and explanation approach. The results of the field study explain, traditional power structures through the Sultanate of Ternate has dominance over indigenous peoples (in term of Ternate language "balakusu se kano kano"), but also hold political power and rule by the agent (Deputy Mayor of Ternate, Arifin Djafar), while the governance structure of Ternate, since the era of Mayor Syamsir Andili with cultural themes or vision-mission, which is "Ternate Towards Civil Society". The era of Mayor Burhan Abdurrrahman, the same things also is done by his vision and mission of "Bahari Berkesan". However, both Syamsir Andili and Burhan Abdurrahman can not set up the town well. The station and the market became the economic area interest between the working units (SKPD). Sociologically, this study concludes that between traditional and modern power, there is a pull so strongly in structural interest that influence and dominate the culture (structure dominated culture), through social action actor with the social practices recursively. The role of the townspeople a processor still not able to negotiate these two forces. Therefore, the urban social development, should be directed to the public interest, and not for the economic and political interest, so that the social integration of Ternate City in the future can be created.
\end{abstract}

Keywords: Actor, City, Power, Social Action, Structure, Culture, Process

\section{Introduction}

Ternate as a city experiencing fluctuating dynamics. Lapian A.B. (in Ammari and Siokona, 2003), recognizes the term town in Indonesia has grown in significance all time. Initially as a Bastion, understanding the city and then used for settlements surrounded by walls, and then used to call the settlement itself, though not surrounded by a wall, but has distinctive properties that distinguish them from rural settlements. Gallion and Eisner (1996), stated that there are two basic forms of the city which can be recognized in the past is a walled city and open city. On the basis of these forms of variegated interwoven pattern, where every shape and design is determined by the character at the time. Further Gallion and Eisner write, cities have undergone a process of continuous change in the shape of all time, and the diversity of its forms is the result of certain forces dominant during certain periods in its history. Departing from the thesis of Gallion and Eisner above, city life early in Ternate was there with the construction Gamlamo (the big country) in the sample was marked by the establishment of a Portuguese fort named Sao Joao (also known by the name of Nostra Senhora del Rosario), founded in 1522.

Traces of the fortress can be seen in the village of Kastela (South of Ternate City), in which the walls of the fort have been fused with the land filled with grass. Alternate sociologically early birth, has been the establishment of a social structure that delivers power relations between the kingdom/sultanate with the colonialists. Moreover, at this early stage the presence of Ternate also generates social stratification so sharp, that the colonials, the sultanate/ indigenous groups, and the general public. In subsequent trips, especially at the end of the new order, the dynamics of the Sultanate of Ternate increasingly felt stronger. This may be indicated by the involvement of the Sultan of Ternate in North Maluku DPD Golkar Party, which was then deposed. This condition is intertwined with the status of North Maluku in the process of becoming a province, regardless of the province of Maluku in Ambon.

One of the significant impacts that gives the big influence of the rise of indigenous strength is the presence of Law No. 22 of 1999 (later changed into Law No. 32 of 2004) is giving an opportunity to autonomous regions to implement direct elections of regional heads. For North Maluku, the implementation of regional autonomy is a great opportunity and a challenge. With the implementation of regional autonomy, to revive the spirit of local forces increasingly thickens. Here, politics later revived through the development of political parties under the new slogan of reform (political reform) and democratization. In a climate of political change that decentralization, ethnicity emerged as a force for mobilizing cultural identity in the political landscape of the post-Soeharto era (Tirtosudarmo, 2013). The aftermath of the fall of Soeharto, indigenous identity was reinstated by actors who hold positions of local power. This identity refers to the political-economic interests, which is to master the opportunities opened regional autonomy government through Law No. 22, 1999 at that time. After a long period of colonial rule and silenced immersed for thirtytwo years of the new order regime, indigenous identity particularly Sultanate Ternate start to rise (raised?). In the development of Ternate City today, the struggle and the seizure of spices has turned into a struggle for spaces of the city with limited land through various city governments and 


\section{International Journal of Science and Research (IJSR) \\ ISSN (Online): 2319-7064 \\ Index Copernicus Value (2013): 6.14 | Impact Factor (2015): 6.391}

party policy of the Sultanate. In the spaces of the city is a productive and economical region, which has become the public's attention outside to come to this small town. Ternate city then stained diverse cultures and ethnic groups of immigrant communities. Here, then, the city is in the process of migration and urbanization which gives effect to the presence of economic action community.

Strengthening the dominance of power between the authorities and the Government of the Sultanate of Ternate City gave the perception and impression that in the future, the city of Ternate there are two powers vying for influence in the development of the city. Although there were, indeed, ideally there is one power, with a permanent foothold in the power of culture and structure. This study uses the perspective of structure, culture, and processes that depart from the following research question: "how the relation of structures, culture and interprocess actors at local level in social integration and social development culture city of Ternate"?

\section{Literature Review}

The focus of theoretical analysis in this study to further explore the theory of Giddens (2010), while to see the landscape of Ternate sociological perspective will be used Structure, Culture, and Social Process of Paul Wirutomo (2012).

\subsection{Anthony Giddens, 2010: Structure and Action in Space Time}

Bernstein (in Priyono, 2002) states that the fundamental goal of the theory of the structure is to explain the dialectical relationship and interplay between agency and structure influence. There are at least two central themes that became the pivot of thought Giddens, namely the relationship between structure and agency, as well as the centrality of space and time. Relationships actors and structures, by the Giddens known relationship between the two as the duality relation in which the actions and structures complement each other, called actors are the ones who concretely in the continuous stream of actions and events in the world. While the structure is not the name for the totality of the symptoms and not the hidden code as in structuralism, nor a linkage frame portion of a totality as in the functionalism. The structure is the rule and resources and formed a loop formed from social practice. Giddens is this duality of the principle of a theory called Theory of Structuration.

While the centrality of time and space is the axis that uses structuration theory, the centrality of time and space is also a critique of static versus dynamic dualism, synchrony versus doctrine, stability versus change. Time and space are usually understood as an arena or stage action, where we go, where we came out. Giddens states that time and space are not an arena or stage action, but the elements that are absolute (constitutive) of action and community organizing. That is, regardless of time and space, no action. For Giddens, for example, differences in the forms of society do not lie in the differences in production as filed Karl Marx, but on the way each society organizing the relationship between time and space. Giddens said the relationship between the perpetrator (action) and the structure in the form of duality relations, occurs in the social practice, repetitive and patterned across space and time. Social practice it can be a habit. Where is the duality between actors and structures in the social practice? According to Giddens, the duality lies in the fact that a structure is similar guidelines which became the principle practices in various places and times are the result of repetition of various actions. Similar schemata rule it is also a means (medium) for the sustainability of social practice. Schemata that structure, so Giddens call (Priyono, 2002).

Giddens completely ignores the role of culture that gives big influence to the structure. Furthermore, Giddens states, as a principle of practice, the structural properties of overcoming time and space (timeless and spaceless) that can be applied to various situations and conditions. In Giddens ideas, empowering structures that allow the social practice. Therefore, Giddens view the structure as a means (medium and resources). For Giddens, the objectivity of the external structure, but is not attached to the action and social practices do. Giddens saw three large cluster structure, namely; first, the structure of signification concerning labeling or symbolic schemata, the meaning, the denominator, and discourse. Second, the structure of domination or domination includes schemata possession of the political and goods/thing (economy). Third, the structure of justification or legitimacy, normative regulations concerning schemata, regarding the rule of law (Priyono, 2002).

\subsection{Paulus Wirutomo, 2012: Relations Perspective Structure, Culture, and Processes}

The perspective of structure, culture, and process $(\mathrm{S} / \mathrm{K} / \mathrm{P})$, Wirutomo (2012), is seen to give an explanation in connecting the previous concepts used in this study. In this perspective, placing the social reality in three dimensions overlapping-related. This three-dimensional according to Wirutomo an important and fundamental concepts of sociology of a society, in order to develop the concept of social development is very systemic-societal. In view Wirutomo (2012), socio-cultural development of the human improvement in the social dimension. Furthermore, Wirutomo revealed that the source-cultural development of even more fundamental than just the alleviation of poverty. Although poverty involves the degradation of human quality widely, but the actual construction of the running for this has a negative impact broader than poverty, which damages the joints of socio-cultural life of man, such as war, violence, terrorism, oppression, human trafficking in short, matters relating to moral degradation and ethical society. These are the fundamental issues of Social Development, so much broader and deeper than just poverty.

The emphasis on social development, according to Wirutomo, (2012), is equity in the provision of infrastructure and the human rights of the most basic, such as the similarity of the opportunity, freedom of expression and selfdetermination, justice, participation, democracy, and others, which better known as social inclusion. The values are at the core of the social-cultural guide that development. For

\section{Volume 5 Issue 4, April 2016}




\section{International Journal of Science and Research (IJSR) \\ ISSN (Online): 2319-7064 \\ Index Copernicus Value (2013): 6.14 | Impact Factor (2015): 6.391}

example, the value of justice, unity, independence, and so forth. Wirutomo asserted, the construction of which only a growth oriented development is clearly not a real because no substance values into reference.

To comb the social reality of Ternate sociologically, researchers used the perspective of structure, culture, and processes. Briefly about the three elements can be explained as follows; structure, according to Wirutomo (2011), the pattern of relationships (especially the power relations) between social groups coercive, rule (imperative), inhibit or constrain on human action (agency). The strength of social structure can be institutionalized that legally (such as laws, government policies, and so on), or not, for example, coercive power of the corporate world that although no legal force officially, but effectively regulate the wider society (through advertising, physical facilities were created, and so on). Therefore, the structural development, that is, an attempt to balance power relations between the government and the people or the rich and the poor through the development of policies and legislation that benefit the people.

Wirutomo (2011), explains that the culture is a system of values, norms, beliefs and all the habits and customs that have been ingrained (internalized) the individual or society that has the power to form patterns of behavior and attitudes of community members (from the inside). A culture that has been embedded in a community is not always the best way of life for the welfare and dignity of the people, according to an Wirutomo as much power always try to maintain the culture in order to protect its interests and oppress other groups through the legitimacy of culture (cultural hegemony). Build a culture, in view Wirutomo (2011), is to improve the quality of the system of values, customs that hinder the welfare of the people or ignorant people either directly (through socialization, education, etc.) or indirectly (through the development of structural and social processes). The cultural development includes; granting the right to life of all elements of culture (multiculturalism); developing the quality system of values, norms, traditions that exist, such as reducing primordial; determining the ideal value as the basis of structural development (through policy, regulation, and so on); Developing structural conditions (policy/regulation) that triggers an inclusive culture.

Processual, although externally the individual is forced by the strength of the structural and molded by culture, but according Wirutomo, humans are not robots. Humans have a space to interact dynamically, where the everyday interactions of individuals and groups to express their aspirations are relatively free from the bonds of structure and culture. Here, there was a negotiation dynamic and creative, discussion, debate, discourse between community members. That social process, this arena can be a source of structural changes as well as the existing culture (Wirutomo, 2012). Social processes are all the dynamics of interaction between community members who have not been structured or culturing. Through the process of social, individuals and groups can express their aspirations relatively freely, discuss, dynamic and creative discourse among members of society, so that this arena can be a source of changes that could negotiate the existing structure and culture.
In real life, structure, culture, and the process does not stand alone in isolation, but to a certain degree intersection (crosscut), support each other, influence each other and a certain degree of inherent (embedded) that forms a complex system (Wirutomo, 2012).

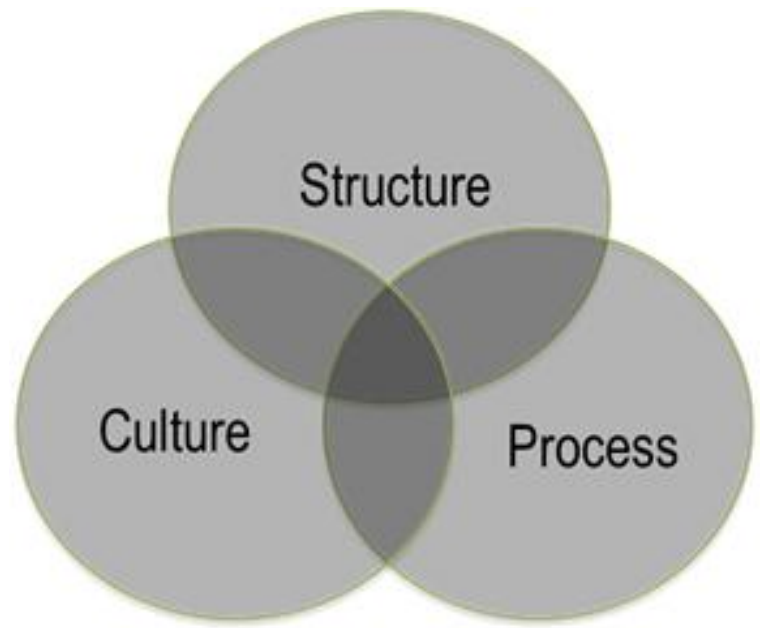

Figure 1: Basic Elements of Society: Structure, Culture and Process

This study departs from the idea of the existence of Ternate, which indirectly has two traditional authorities and the power of rational legal authority. Traditional authorities that are in the institution of the Sultanate of Ternate, and the rational legal authority would be in Ternate City Government. As the region is loaded with the customs and values of Islam, known as adat se atorang, Sultanate institutions did not escape the pull of political interests and power. Involvement in the political realm solely to promote the progress of the Sultanate institution with all the potential of tradition, which is precisely to strengthen traditional authorities that already exist. Contiguity actress sultanate with the political area is not new. In early history, the Sultanate of Ternate is always being on the political intrigue is so sharp among the Colonial.

\section{Conceptual Framework}

\subsection{The Scramble of City Space}

The term city in Indonesia has grown in significance all time. Initially as a Bastion, understanding the city and then used for settlements surrounded by walls, and then used to refer to the settlement itself though is not surrounded by a wall, but which have distinctive properties that distinguish them from rural settlements. (Lapian, in Ammari and Siokona, 2003). Nas and Boender (in Nas, 2007), the city could be seen as a total social phenomenon. That is, the town relating to various aspects of good material, as well as social, cultural, linguistic, political and economic. As a result, the city was subjected to the concentration of the entire community interaction, including rural communities. No exaggeration, if within this framework, the city, according to Aidan Southall: "... is what a historical society decides the city will be." Thus, the connection with the city, continued Southall, "urban is the social meaning assigned to a particular spatial form of historically defined society (Nas and Ansari, 1985). The city, even urban life, is determined by the people who live in it. In 


\section{International Journal of Science and Research (IJSR) \\ ISSN (Online): 2319-7064}

Index Copernicus Value (2013): 6.14 | Impact Factor (2015): 6.391

a lot of literature, especially the leading ideas on urban development, seen how the city is an important entity in economic development. David Harvey (1985), the urban capitalization process is "... implies a material creation of physical infrastructure for the production, circulation, exchange, and consumption". From the perspective of Harvey can be understood simply, that various forms of urban development cannot be separated from the accumulation of capital, because of that, the city was formed, lived, and engineered by first of all as the room.

Meanwhile, Hans-Dieter Evers (1995: 58-59), see the city as a vast field that has been divided into small areas (plots), each of which has been recognized by a particular individual or group. But with the changing structure of the city's most happening continuously, according to Dieter Evers termed transplosi, then these fields can be claimed by individuals or groups. Transplosi according to Dieter Evers, is the sudden expansion of the urban population. Transplosi encouraging competition to get living quarters. Seizing the space according to Evers is basically the seizure of land for certain purposes by individuals or groups of people. McKenzie (in Basundoro, 2013) termed the process of seizure of the town hall as an invasion of space. According to the invasion process is divided into three levels, namely the initial stage, secondary stage, and the climax stage. The process of invasion marked the beginning of their symptoms geographical invasion of a social group, and then meet the challenges of the existing population in the affected area expansion. In the next stage, the competition is getting better and then followed the process of displacement, selection and assimilation. The intensity of the displacement process, selection, assimilation is largely determined by the nature that expands nor expanded. For this study, the focus of urban space is a market researcher, terminals, and land area in Ternate.

\subsection{The Power}

General rules according to Max Weber (Giddens and Held, 1987: 23-24) is an opportunity for a person or a group of people to manifest his will in the form of a social action either against those who oppose the will or against that followed. Economically conditioned power is not synonymous with power in the real sense. On the contrary, the rise of economic power is the result of the absence of power which are based on other factors. Weber says further, people do not just want to get power to enrich themselves economically solely. Power and economic power can be judged according to the essence of each. Not uncommon for people to want to come to power, because of social honor. But the sheer economic power, especially power based on money alone, is not an honor or prestige social foundation recognized. Power alone is also not the basis of social honor. Ternate city formerly known as the area is loaded with the values of traditional authority by relying on the values of religiosity (Islam), before finally being approved as a municipality/city. In its development, the city is up to now still retaining the values of the traditional powers, side by side with modern bureaucratic power through the government of Ternate. Of course, as traditional territory, natural perspective of thinking people of Ternate so patterned as the intelligible world empire. The sultan is at once the concrete legitimate authority. Tony Rudyansyah (2009), in his research on the culture of the Sultanate of Buton, outlining how the Sultan Buton formed. The sultan in implementing and organizing authority addressed his people get the support of the supernatural powers (the Almighty). Sultan in the sultanate of Wolio be regarded as the most concrete manifestation of God (Allah SWT., in nature, or as Wahdat al Wujud in the terms used in Murtabat Tujuh, which is the constitution of the Sultanate. In macro-sociological study, discussion of the structure is the most important thing. Structure talk about something that is composed of parts are interdependent and form a certain pattern, which may consist of a pattern of behavior of individuals or groups, institutions, and communities. Theoretical sociology, cultural systems as the social system occupies a very important position, so Talcott Parsons also said, as important-even more important structural importance of the cultural system for the social system (Ritzer and Goodman, 2003).

\subsection{The Social integration}

Randall Collins (in Paul Wirutomo, 2012) asks the fundamental question of sociology why society is formed, which makes people remain bound in it. According Wirutomo, this question shows how important the concept of social integration in the study of sociology. The phenomenon of integration seen in the many diverse perspectives and different. One definition of the proposed neutral and freely translated by Wirutomo who followed Richard Scott, coherence and unity between the units which are members of a social organization. On the concept of integration, there are social integration and national integration. By Wirutomo, better social integration and national integration is distinguished in three properties, namely normative integration, functional integration, and coercive integration (Wirutomo, 2012).

\subsection{The Authority}

Max Weber (in L. Laeyendecker, 1991) mentions the legitimate authority is the authority, which is dividing respectively; rational authority, traditional authority and charismatic authority. In a system of rational legal authority, according to Weber, can only thrive in modern Western society. In rational-legal system that is modern bureaucracy can develop. Other communities in the world, added Weber, still dominated by traditional or a charismatic authority system which generally inhibit the development of a rational legal system and modern bureaucracy. Weber also saw traditional authorities have a concept that can hardly be disputed. One aspect of traditional authority that could be incorporated into charismatic authority is the "sanctity", because the tradition is one that forms the basis of sanctity and that can only be used as a model that can be purified and incorporated into the traditions (Martin, 1993). In addition to the above authority, question authority has also become so important in this context. In the view of Weber, as quoted by Ralf Dahrendorf, the authority is likely to govern which with a certain special willingness obeyed by a certain group of people. Dahrendorf (1986), an important difference between power and authority actually lies in the fact that the powers 


\section{International Journal of Science and Research (IJSR) \\ ISSN (Online): 2319-7064}

Index Copernicus Value (2013): 6.14 | Impact Factor (2015): 6.391

are basically related to the personality of the individual, whereas the authority is always related to one's social position or role. In this case, the authority can be described as a legitimate power.

\section{Results and Discussion}

The torrent is a small area since the beginning, besides forming from local communities, the role of myth and legend so strongly present that form of social and cultural structures. This was later confirmed by the symbols that refer to Islamic values. Strengthening the values of Islamic religion, not only be a world view for the Muslim community in Ternate and also applies to areas of the kingdom in North Maluku (Tidore, Bacan, and Jailolo), but also shows the efforts to strengthen the status of power Kedaton Centric, as contained in the idea of the power of Java. The formation of this value is very effective localization to maintain social integration Ternate of North Maluku are. The views are the values of the kingdom/sultanate was then formulated in such a way, includes the cosmological side transcendence that became known as adat se atorang. In a way, then, in the direction of social change, indigenous culture se atorang was then structured, culture is structured and internalized by Regulation No. 13 of 2009 to be a means of integrative when a variety of social problems in the city of Ternate comes with an increasingly alarming. The violent conflict between people, and the emergence of behaviors that are far from the ideals together, is partly an indication of the concerns. However, the effectiveness of customs value of adat se atorang is absolutely no significant impact for the structuring attitudes and behavior of citizens. suspected, because traditional values of se atorang is better to have the charges politically, demonstrated through action of actor Sultanate of Ternate more diligently to build relationship power than developing traditional values of se atorang. Involvement of Sultan Mudaffar Shah and Boki Nita Susanti in the political realm, it is an attempt to preserve the traditional values that exist, as well as to strengthen the rational authority that can influence government policy.

The entry of Arifin Djafar as Vice Mayor of Ternate, the involvement of the Sultan of Ternate and his queen in the area of politics, can be read in the skeleton to have and strengthen the legal rational authority. Thus, traditional authority and charismatic authority are expected to be an integrative force function is not maximized. Therefore, there is an attempt to encourage the Sultanate of Ternate to a world of bureaucracy as the establishment and strengthening of rational authority, so that the interest to the maximum the Sultanate of Ternate work in the urban space. Open conflict between the Government of the Sultanate of Ternate, related to the construction Hypermart, where the Sultanate threatens to dismantle the shopping center, which was inaugurated on December 5, 2013 and by the Mayor of Ternate, be a strong indication yet awakening of harmony between local actors in Ternate. Here shows how the pattern of power relations is not yet equal. The Sultanate still felt to have dominion over a wide range of development in Ternate. This context shows no effort culture structured, or authors call structuring culture.
The implementation of socio-cultural development in the city of Ternate, indeed, face challenges that influence the development of the city. On the one hand, as the city government is governed by the rules in a rational, bureaucratic and formalistic, but on the other hand, the city is also still required to run traditional values se authoring through local institutions were very influential, namely the Sultanate of Ternate. So that, in any political process that took place in the city of Ternate, cultural color and ethnicity Ternate so thickened and strengthened. In this position, the frequency of the Sultanate of Ternate in determining the direction of selection of indigenous peoples. In addition to being a means of collecting votes for citizens who have an emotional attachment, as well as an effective means of pressure groups to control social solidarity residents. The mayor of Syamsir Andili era, Ternate customs and symbols of Islam is so strong coloring culture reign. Syamsir Andili color of Islam strengthened and brought the vision and mission making Ternate ss the City of Culture towards Civil Society as an effort to represent the leadership of the Prophet Muhammad when building Medina. While the colors in the Government Syamsir Andili culture are also a powerful marker of their symbolic resistance to the dominance of the Sultanate of Ternate. The housing development, Office of the Mayor, the construction of the Al-Munawar mosque, are symbols of resistance in the intention, as well as the realization of the vision and mission. But on the other hand, Syamsir Andili also accommodating relations with the Sultanate of Ternate. This can be demonstrated by laying the symbol of one banner kingdom of Ternate (Ikan Pari) on the emblem of the City Government of Ternate and issuance of law No. 13 of 2009 on the Protection of the Rights and Indigenous Cultural Sultanate of Ternate, in other words, there is an effort to make cultured structure.

Vision and Mission era Syamsir Andili - Amas Densie inclusive, is read from the words making Ternate City as the city of culture, which is elaborated into mission through sentences; self-esteem, identity, and upholding the values of religion and humanity, civilized in harmony with the urban environment so nuanced culture of Ternate and contributing to society economically powerful city. The existence of the informal sector to the formal balance and equitable urbanrural prosperity through the provision of urban infrastructure. The formulation of the vision and mission above, indirectly contain the potential to address the structural-culturalprocessor. The first step is to set the Andili Syamsir city, by performing the reclamation as a strategy in anticipation of limited land. On reclaimed land that is woke market and terminal Gamalama, which is still used, replacing the previous market conditions that are not representative. Also setting 1000 market stall, even if ultimately not be resumed. Step Syamsir This is an effort to structural development, as Syamsir Andili trying to change the pattern of market presence and terminals previously is no longer effective because besides limited to a narrow area, as well as market presence and terminals located in the city center, which would greatly disrupt the activities of citizens.

Likewise, site preparation for street vendors selling point with building market stall in 1000, was prepared for merchants who do not have a place to sell, is both a major 


\section{International Journal of Science and Research (IJSR) \\ ISSN (Online): 2319-7064}

Index Copernicus Value (2013): 6.14 | Impact Factor (2015): 6.391

step construction of cultural for the arrangement of street vendors. Syamsir Andili also issued a regulation by Regulation No. 042003 on Regulation and Development of Street Vendors in Urban Ternate, this is a cultured structure also structured culture. Market development, terminals, locations for street vendors and regulate street vendors -yet later the law does not go unheard and unused-Syamsir Andili not just do a development that is sectoral but contains elements of the development of social culture for development efforts socio-cultural quality of life for the people of Ternate city. But then what has been built, are not consistently developed, operated, and maintained. The same thing happened in the era of Mayor Burhan Abdurahman, where cultural aspects are also still feels stronger, which is contained in the vision and mission; realization Ternate into town cultured, the religious, harmony, independent, fair, and insightful environment, which later shortened and become jargon municipal government, "Bahari Berkesan". The aspect of culture / customs at the Government Burhan Abdurahman, may not be as responsive and cost-massif with what the government of Syamsir Andili, so that, in many agendas governments of Ternate, especially the aspect of culture/indigenous only to continue what has been done the previous administration. Moreover, an understanding of the culture is more focused on artistic aspects alone and not the value that can be modifiers attitudes and behavior. The most dominant characteristic of the Government Burhan Abdurahman is the structural development economics, namely the Maritime Hygiene Market Memorable, and Hypermart in cooperation with the private sector. The Hypermart development and reclamation of location Tread 1 Plus, judged to have come out of the Spatial Plan (RTRW) Ternate City Government has been prepared beforehand. Hygienic Market development is intended to provide a new culture for merchants to be more organized. In fact, the market is even more disorganized hygienic.

The vision and mission of Burhan Abdurahman-Arifin Djafar described above is very potential to address the problems faced by people in Ternate, in addition to be structuralcultural-process, development offered Burhan AbdurahmanArifin Djafar also contain elements of social development culture that expected can improve the quality of sociocultural better in Ternate. The content of the nature of cultural-structural-process, can be seen from the work programme, in particular the field of regulation of the city, it is found in the phrase; setup, control and utilization of urban space matching between the needs and the carrying capacity of the land is the construction of structure. Equally known, where Ternate has limited land, of course, control of urban space is very important. But here, then the cultural aspects are not visible, because in fact, the townspeople more precisely builds / construct buildings to ignore this aspect of this arrangement. Another thing to be a "constraint" is the status of the land is still under the authority of the Sultanate of Ternate with customary land. Sometimes Idin (a sort of permission from the Sultanate) are out to reduce city government regulation about land use.

For the development of other economic areas, the Government established PT. Bank Rakyat Syariah (BPRS) Bahari Berkesan. This is a structured development, which is then amplified by regulation through Perda No. 27 In 2011, on the establishment of PT. BPRS Bahari Berkesan. Also establishment hygiene market Bahari Berkesan reserved for spice merchants and traders wet fish. Establishment PT. BPRS and hygiene market at the same time have the effect of educating the community at large, for the empowerment of the weak economic income people. This is one manifestation of the Educating City, which contains elements of "cultural" boosted by regulation, there is an element of culture that is structured, in the words of the author: cultured-structure. While in the field of health, Burhan Abdurahman-Arifin Djafar build Pharmacies Maritime Memorable earmarked for the grassroots to buy drugs, giving Jamkesda, as well as providing assistance to families who can not afford surgery and treatment referrals to hospitals Ternate or out of the region, giving incentives to health personnel remote areas, as well as free services at all health centers. The step of Burhan Abdurahman-Arifin Djafar with health policy is an attempt to organize a pattern of power relations between the people and those who have power in the field of health. This reality is a condition that is structured and cultured already so deeply rooted among the people of Ternate. Which became the similarity of the two mayors is not yet well established city space arrangement in a more orderly. On the market and terminal, conflicts over economic resources, Giddens call with allocating resources, so thick and always repeated. Both between the driver and the taxi operators, drivers and street vendors, drivers and government officials relevant agencies. The Management of terminal and market, nor governed by Regulation No. 09 Year 2010 about trminal retribution, and Regulation No. 10 Years 2010 about market retribution. In fact, the rationalization arrangement of street vendors, who already has regulations through Regulation No. 04 of 2003 at least to be a rule in the regulation of street vendors, in fact, this law did not look run. Neither the era Syamsir Andili and Burhan Abdurrahman.

Instead, it became the source of acts of irrational of government officials such as illicit payments to vendors, rental places that are not supposed to do, the omission of public facilities in the market and the terminal to be a special space like as, restaurants in the terminal, karaoke room and cafe in the market. Even allowing operation of the New City Market without government control. About chaos and terminal markets and other city hall are not fully supported by clear and strict regulation. Arguably, the vision-mission Syamsir Andili Government and Government Burhan Abdurahman more emphasis on aspects of customs / culture. While the socio-cultural aspects of citizens, altogether less attention, if not to say the least. Always the presence of attitudes and acts of violence between residents, and extortion have become a strong indication that the arrangement of social-cultural aspects of the city of Ternate not awaken properly. In other conditions, the strong economic development makes city government under Mayor Burhan Abdurahman-Arifin Djafar further pursue economic growth, lack of attention to the social aspects at lower levels. Poverty and high unemployment, as well as the seizure of resources in the economy in the market and even more in the terminal outside the ethnic dominance, don't rule out the possibility of the presence of suspicion and jealousy among residents. Then less internalized of se atorang customary in

\section{Volume 5 Issue 4, April 2016}




\section{International Journal of Science and Research (IJSR) \\ ISSN (Online): 2319-7064}

Index Copernicus Value (2013): 6.14 | Impact Factor (2015): 6.391

society as a whole, making the city of Ternate as if nothing had power normative powerful integration to become more functional.

Burhan Abdurahman - Arifin Djafar also provides a public space in front of the Masjid Al-Fajri Falajawa built a small garden beach front, known as the Garden Beach Falajawa and Nukila Park. Then there are Ela-Ela Festival and Festival Kora-Kora. Also, activities of the party of the people, when the anniversary of Ternate, each ahead of the 29th of December. Even so, Burhan Abdurahman-Arifin Djafar plans to build a public space of interaction in front of the former Office of the Governor, indirectly, the form of social-cultural contain aspects of process and interact in which the public space that citizens interact with each other to break the ice tension the lives of city residents.

Ternate city not just as an administrative region government continues with physical construction with the preparation of infrastructure and supporting facilities are modern for its citizens. But more than that, Ternate has long historical roots of the colonial era with regard to the identity of the actors fight to obtain greater economic resources which implies the existence of Ternate today. As former colonies, the planting of ideology colonists on Ternate very deeply felt. During this time, the direction of social-cultural development of the city of Ternate can not be detected whether the construction is done touches on the interests of citizens or not, the success of development is almost always measured in purely economic aspects, not social aspects of cultural life. A year later, in 1999, was born the Regional Autonomy Law No. 22/1999 (Law 32/2004) where the power is given to the widest area (autonomously) to manage resources that exist. In a situation like that, the structure of the power of the customs started to be raised. Not only, but also Tidore Ternate. Be then, the structure of the power of the Sultanate began widespread and deep actively involved in the fight domination and legitimacy in the political realm.

For the structure of the government of Ternate, the Sultanate of Ternate successfully pushed Arifin Djafar (people in the Sultanate) as Vice Mayor of Ternate Ternate accompany Mayor Burhan Abdurrahman for a 2010 / 2015 period. The rise in this pair, after going through Ternate Mayor Election in 2010 cannot be separated from the full support of the Sultanate of Ternate and Tidore Sultanate, as Mayor Burhan Abdurrahman ethnic Ternate Tidore. It can be said, the power of culture, mores successfully structured. With the inclusion of the Sultan in the political structure (as DPD-RI), and Arifin Djafar presence in governance structure (as Mayor of Ternate), shows that pull the interest structure in the city of Ternate is so strong. In view of Giddens, what does the Sultanate, including the government of Ternate is an action that is based on practical consciousness, which is backed up by the legitimacy and power of authoritative resources to manage resources in allocative owned Kota Ternate. With existing strengths, rules and resources are organized into social systems (structures), which then build relationships reproduced between actors (among the Sultanate and the government of Ternate) to generate social production (the system). Here, then create conditions that enable sustainable structures that exist to reproduce the social system (structuration), including efforts to manage and organize a wide range of economic resources that exist. Sultanate of Ternate is an institution that has a traditional authorities at the same charismatic authority, which of course can be the antithesis to the existence of modern bureaucracy, as well as that of the Government of Ternate, so that the action taken is entering the political realm to be able to have the authority of the rational-legal. Social and cultural development of the city of Ternate above description can lead to social inclusion, it is here, we need a support to strengthen social-cultural development which were formulated expressly and fair. During this time, the direction of social-cultural development of the city of Ternate can not be detected whether the construction is done touches on the interests of citizens or not, the "success" of development is almost always measured in purely economic aspects, not social aspects of cultural life.

Similarly, social processes in Ternate, the presence of more free space for each other to develop the quantity and quality of social life through social interaction, has not been able to walk significantly. Mutual suspicion, both at the level of bureaucracy and in the body of the Sultanate of Ternate so fertile. It is then patterned on the social life of citizens, which is so easy it is present attitudes and violence among citizens. Therefore, social development and culture become so urgent social integration developers to build a more dignified for others. Here the role of the City Government to develop functional integration required so as to create normative integration together as expected. Therefore, the strength of the city of Ternate, in the form of customs and teachings of Islam should be a system of values and norms that need to be continually socialized into a force that can awaken social integration into the goal with the citizens. With the power of this social integration, the rate of change of globalization and modernity is happening in the city of Ternate can minimize a variety of social problems that occur in the future.

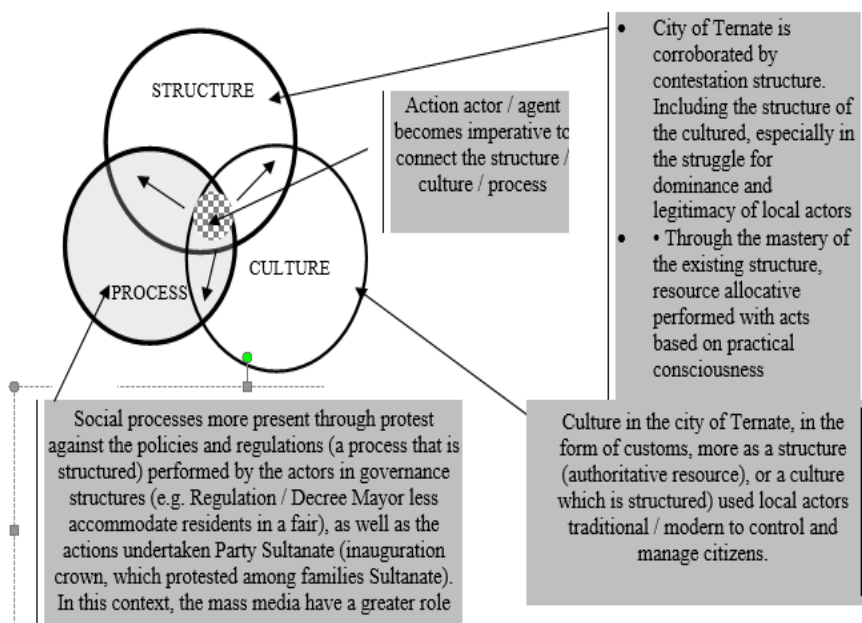

Figure 2: Readings on the reality of Ternate city can be seen in the perspective of Wirutomo, 2012.

Using Giddens analysis and perspective structure, culture, and processes in understanding the power of Ternate city in two, can be seen in the mapping structure of signification, structures of domination, and the structure of legitimacy. In the third structure, perspective of Wirutomo then equip it with an explanation affirms at the same time, that happens 


\section{International Journal of Science and Research (IJSR) \\ ISSN (Online): 2319-7064}

Index Copernicus Value (2013): 6.14 | Impact Factor (2015): 6.391

between the structure-agency (by Giddens) applies patternstructure-culture-process.

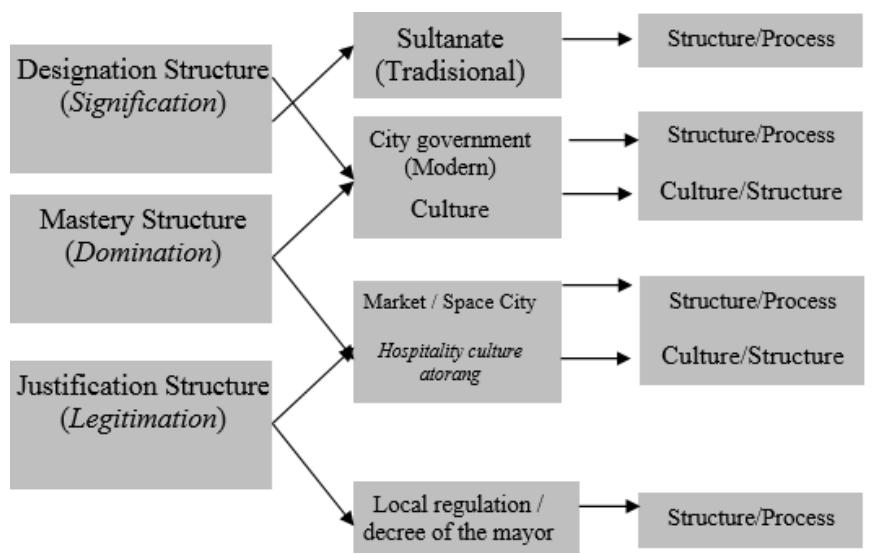

Figure 3: Linkage Teoritisasi Giddens and Perspectives Wirutomo

Three elements of Wirutomo perspectives: structure-cultureprocess, indirectly not take into account how the steps in negotiating conflict. Especially negotiate between actors (agency / individual) at the level of the social system that each hold dominance and authority (in this case structural). It may have on the structural element when it has been internalized, but until when the strength of this structure is internalized. Therefore, it is a necessary understanding about space-time to understand a force structure becomes more internalized. Say so, because the space-time becomes "limit" until when the internalization process it should be patterned. Here, then, strong involvement of social action agency to be able to move from one element to another to negotiate the interconnection between these elements. The Wirutomo structure for a pattern of relationships which "play" outside the system of coercion (coercive) rule (imperative), and even curb (constraining) the individual or society. Such a structure would not be patterned in order to influence the individual or community, unless there is a value system (culture) are internalized. The internalization process is a social act through social practices to establish a model for social order. Therefore, the authors refer to it as Structuring Kultur, or borrow a phrase Wirutomo as "The structure of the cultured". That is a process of structural conducted continuously to become internalized culture. Instead, the system of values, norms, habits in this concept is known as culture, will not be a role more leverage, when the role of the structure is also weak. Therefore, the authors refer to it as Kulturisasi structure, or in terms Wirutomo referred to as "Kultur The structured" is an effort of values and norms to be compliance with the individual and society. As for the process, for the author is most vital, then the piece structure and culture, or vice versa, this process element is always inside and become an integral part (embedded). This process should be driven by what the actor.

While Giddens mentions power as a result of the reproductive structures of domination, which is done through allocate resources and authoritative resource, where the resource allocating more reliant on the ability to collect the material resources and authoritative resource which is the ability to organize and manage resources. Giddens has not provided an explanation of how the resource is shared or divided after the existing agencies, or distributed. By the author, distributive resources become important in the structure of power domination. Resource distributive an attempt was made actors / agents in controlling and managing on what you already have. For example, the structures of domination and legitimacy, if the agent / actor is not able to manage what the power, then power it will have implications for the social system as a whole. It can be seen from the case of corruption, for example. In reality, power and dominance, it will hit when it relates to distribution issues, and this is where the conflict is often present. In this context, there was no explanation Giddens. Explanation Giddens was more referring to the matter of practical consciousness as an important core structuration theory of his, namely an awareness involving an actor correctly (based on regulation, legitimacy and dominance) without using words (the authors call it discourse) with what it does. Here, then, Giddens gives justification to an action actor, even though regulations (as a true representation) that has intentions to take control of the resources available. Giddens is based on the structure agents. That is, Giddens more reliant on structural problems and actions, but the culture seems to have not received confirmation Giddens as how the actions of the actors performed on the structure of the agents, even if implicitly actual issue of culture was actually already part of the analysis Giddens, one of which relates to action through social practice done repeatedly. Likewise about the process, the analysis of the actual Giddens has observed that processes, namely the social action agency. That this action becomes essential for the structure, this is the case, the structure becomes important to the action. Reciprocal relationship between structure and action as well as action and the structure is a process itself. Both Giddens and Wirutomo, two exchange gains and filling up the element which is used as an analytical tool, said to be complementary or reinforce can be described in the following table. 


\section{International Journal of Science and Research (IJSR) \\ ISSN (Online): 2319-7064}

Index Copernicus Value (2013): 6.14 | Impact Factor (2015): 6.391

Table 2: Mapping Theory of Structuration Giddens and Perspective Wirutomo

\begin{tabular}{|l|l|l|}
\hline \multicolumn{1}{|c|}{ Structure-agent } & \multicolumn{1}{c|}{ Wirutomo } \\
\hline $\begin{array}{l}\text { - The rule } \\
\text { - Resources } \\
\text { - Social Actions } \\
\text { - Inter curb (constraining) and delivered (enabling) } \\
\text { - Influencing individuals and society from within }\end{array}$ & $\begin{array}{l}\text { - The pattern of relationships } \\
\text { (power) between social groups. } \\
\text { - Inter force (coercive), govern, } \\
\text { (imperative), and the curb } \\
\text { (constraining) } \\
\text { - Influencing individuals and } \\
\text { communities from outside }\end{array}$ & $\begin{array}{l}\text { For the author, it affects the structure } \\
\text { of the individual and society from the } \\
\text { outside or from within }\end{array}$ \\
$\begin{array}{l}\text { - There is no explanation about the culture in detail } \\
\text { Giddens }\end{array}$ & $\begin{array}{l}\text { The system of values, norms, } \\
\text { beliefs, habits, and customs that } \\
\text { have been ingrained, so it has the } \\
\text { power to form patterns of behavior } \\
\text { and attitudes of community } \\
\text { members (from inside) }\end{array}$ & $\begin{array}{l}\text { The author actually find that Giddens } \\
\text { fact explains the culture (implicitly) } \\
\text { that the explanation of "Practices of } \\
\text { Social recursively" (repeated). } \\
\text { Repeated actions would form a habit. } \\
\text { Habits are part of the culture, because } \\
\text { it will give birth to internalization. }\end{array}$ \\
\hline $\begin{array}{l}\text { There is a detailed explanation of the process of } \\
\text { social }\end{array}$ & $\begin{array}{l}\text { All the dynamics between } \\
\text { community members who have not } \\
\text { been structured and culturing }\end{array}$ & $\begin{array}{l}\text { The author assesses the concept of } \\
\text { "Social Action Factors" of Giddens is } \\
\text { a social process }\end{array}$ \\
\hline
\end{tabular}

The city of Ternate in the future with the application of the Theory of Structuration Anthony Giddens, as well as perspectives Wirutomo: Structure, Culture, process, especially for the continuity of government of Ternate, can be transformed into one city one power of attorney, if the role of the structure of the culture really can act stronger and more effectively.

It can be observed when various policies / regulations (structure) can give strength to force (constraining) and becomes a value / social norm for actors (culture) of the commitment to develop the culture of customs Kota Ternate. That is, the support of the customs, should be done without loaded with political interests. Strengthening cultural Kota Ternate to do with the strengthening of the budget for the development of cultural / local culture. In this context, in addition to strengthening the values of government as well as the demands of good governance, Ternate was also corroborated by the values of culture can be a guide for the modern institutional actors. For the city of Ternate, the role of culture in the governance structure and the need to "force" to keep the identity of Ternate as the area known as the customs area. Therefore, it is important structurally strengthened, especially the rule and resources.

Characteristic of Ternate city as a regional custom (culture) should be reflected in the rules of government, as long as it contributed to the Government's performance Ternate better in the future. Thus, the formulation of customs (culture) in accordance with the government's performance breath Ternate should, wherever possible, be reflected in the rules made in accordance with the needs of the development of culture, especially about values and social norms. In a bureaucratic government structure, culture, the process must synergize with the Sultanate, which also shore up the structure, culture, processes in Ternate, so Ternate even if will run as a modern city, but also supported by the strength of the structure, culture, process of the Sultanate, in symbiosis materialism and not competing for positions and interests.

\section{Conclusion}

This study tried to see the landscape of Ternate sociological problems. Therefore, the researchers departed from the perspective developed by Wirutomo with three elements social development culture; structure-cultur-process. These three elements are so helpful to see in detail each of the existing problems in the city of Ternate, in the end, the researchers obtained a thesis of this study, that sociologically Ternate city is controlled by the structure, even if the exposure is there, culture cling among the indigenous people of Ternate, but then there may be mentioned, the strength of the culture is not yet internalized. Economic development programs conducted by the government of Ternate, on the one hand it has encouraged the growth of significant economic growth. However, on the other hand, economic growth has not directly provided an empowerment for the community in general, especially at the micro level. What happens then, citizens and government officials scramble spaces of interest for profit, woke structure, economic behavior that are not managed properly. Government officials are expected to become social agents to enforce rules and regulations are structured, by building a system of cultural values through rationality-legal authority inherent in the bureaucracy, has not materialized at all evident in attitudes and behavior.

Value culture through customs and values of religiosity (Islam) should be able to create a space socioeconomic structure that is more equitable, and can develop the ethos seeks stronger in the community. In fact, citizens prefer as a civil servant, so the business opportunities more ethnic controlled from the outside. At the macro level, government policy should set up circulation of economic development faced by the people in a fair, and not let certain social groups mastering economic centers uncontrollably. Social processes also occur in the city of Ternate, but it was more due to the policy generated by existing structures, both among traditional institutions (empire) and the modern institutions (the city). But a social process that is expected as a citizen initiative in establishing the dynamics are very low. The 


\section{International Journal of Science and Research (IJSR) \\ ISSN (Online): 2319-7064}

Index Copernicus Value (2013): 6.14 | Impact Factor (2015): 6.391

process is structured at present even more dominated by political problems.

The tent city is located on the two powers, namely the traditional and the modern. As the town is laid out based on the spirit of autonomy and the modern bureaucracy, it is still a cultural force (traditional powers) through the Sultanate of Ternate who at any time are always working to institutionalize indigenous se atorang as the power structures that should be a way of life (world view) for the residents Ternate city. A tent city in the future, not only apply two powers, which is loaded dualism, but also the power that applies in duality. Ideally, Ternate City will be in the power where the structure will strengthen the culture, including the rules and resources, to provide an opportunity and more free space for cultural development.

\section{Recomendation}

Some of the recommendations to be considered for the continuation of the city of Ternate in the future, as well as efforts to encourage urban social development more just and humane. Here are some recommendations, academic; first, an increase in the effective dissemination of indigenous traditions and values of Islamic religiosity is becoming a social modality for strengthening integrative citizens; second, Ternate City Government policies need to prepare a regulatory instrument seriously and consistently can be a force to oversee the various programs undertaken; third, structural balanced development in the power relations, power relations, in an inclusive and participatory needs to be developed; fourth, the strength of the culture through the traditional institution of the Sultanate of Ternate, will still be in the process of finding a harmonious form of urban life in the future; fifth, The Power of Two Cities is the study of Urban Sociology of Social Development, which is expected urban development policy is more geared to the public interest is not solely economic and political interests; sixth, to negotiate two powers in the city of Ternate, at least, the spaces of interaction townspeople through a social process, both to institutions of traditional and modern institutions become important to be open to the maximum extent; seventh, the development of the city of Ternate in the future requires a great scenario for the effort to negotiate two powers into one authority.

\section{References}

[1] Ammari, Fachri and J.W. Siokona (Editor) (2003); Ternate, Ternate City Government Publisher.

[2] Basundoro, Purnawan, (2013); Seize the city space, Action 1900-1960 Surabaya Urban Poor's, Publisher Margins Left, Serpong.

[3] Evers, Hans-Dieter, (1995); Urban Sociology: Urbanization and Land Disputes in Indonesia and Malaysia, Publisher LP3ES, Jakarta.

[4] Evers, Hans-Dieter and Rüdiger Korff, (2002); Urbanism in Southeast Asia; Meaning and power InSpace Social Space, Publisher Yayasan Obor Indonesia, Jakarta.
[5] Gallion, Arthur B, and Simon Eisner, (1996); Introduction to Urban Design, Design and Urban Planning, Fifth Edition, Volume 1, the publisher, Jakarta.

[6] Giddens, Anthony (1979); Central Problems in Social Theory, Macmillan, London.

[7] Giddens, Anthony (1984), The Constitution of Society, Outline of the Theory of Structuration, University of California Press, Berkeley and Los Angeles.

[8] Giddens, Anthony and David Held, (1987); Classical and Contemporary Debates Regarding Group, Power, and Conflict, Publisher Rajawali Pers, Jakarta.

[9] Giddens, Anthony (2001), Runaway World, How Globalization Remodel Our Lives. Publisher Gramedia, Jakarta.

[10] Giddens, Anthony (2010); Methods of Sociology, New Rule-Rule, Student Library, Yogyakarta.

[11] Harvey, David, (1985); Urbanization of Capital, Basil Blackwell, UK.

[12] Layendecker, L., (1991); Tata, changes, and Inequality, An Introduction to the History of Sociology, Publisher Gramedia Pustaka Utama, Jakarta.

[13] Nas, Peter J.M. and Welmoet Boendar; (2007); "The city of Indonesia in Urban Theory," in Peter J.M. Nas, Cities Indonesia, Anthology, Publisher Gadjah Mada University Press.

[14] Priyono, B. Herry, (2002); Anthony Giddens, An Introduction, Popular Library Publisher Gramedia (KPG), Jakarta.

[15] Ritzer, George and Douglas J. Goodman, (2003); Sociological Theory, Sixth Edition, McGraw-Hill, New York.

[16] Rudyansyah, Tony, (2009); Power, history, and Action, Publisher Rajawali Pers, Jakarta.

[17] Wirutomo, Paul, (2012), Sociology Jakarta: Towards Social and Cultural Development, Publisher LPMJ, Jakarta.

[18] Wirutomo, Paul, et al, (2012); Social System Indonesia, Publisher UI Press, Jakarta.

[19] Wilson, Chris, (2005); "The Ethnic Origins of Religious Conflict in North Maluku Province, Indonesia, 19992000," Indonesia, Ithaca (Cornell Southeast Asia Program), 79, in April.

[20] Wirutomo, Paul, (2011); "Social Development Policies on Informal Sector in Solo," in the International Journal of Administrative Science \& Organization, Vol. 18, No. 2, May.

[21] Zelifer, Vivian, (1988); "Beyond the Polemics on the Market: Establishing a Theoretical and Empirical Agenda", Sociological Forum, Vol. 3, No. 4. 